\title{
Interrole Conflicts and Psychological Distress in Male Managers and Professionals: The Mediator Effect of Social Problem Solving
}

\author{
Eric Jean ${ }^{1} \&$ Lise Lachance ${ }^{2}$ \\ ${ }^{1}$ Department of Management, Université du Québec à Chicoutimi, Canada \\ ${ }^{2}$ Department of Education, Université du Québec à Montréal, Canada \\ Correspondence: Eric Jean, Department of Management, Université du Québec à Chicoutimi, Canada. E-mail: \\ eric.jean@uqac.ca
}

Received: December 20, 2014

Accepted: January 15, 2015

Online Published: February 27, 2015

doi:10.5539/ijbm.v10n3p15

URL: http://dx.doi.org/10.5539/ijbm.v10n3p15

\begin{abstract}
Managers and professionals are among the workers most at risk of experiencing high levels of conflict between their roles as workers and as parents. Depending on an individual's ability to solve problems in their day-to-day life, these conflicts can affect their psychological well-being. Research examining the psychological distress resulting from these conflicts focuses almost exclusively on women. This study examines the mediator effect of problem solving on the relationship between interrole conflict and psychological distress among male workers. A sample of 291 male managers and professionals living in dual-earner couples completed an online questionnaire. The results confirm a mediator role of problem solving abilities, specifically negative problem orientation. Further research on training programs could examine the effectiveness of developing problem-solving skills in managers and professionals.
\end{abstract}

Keywords: interrole conflicts, psychological distress, male managers, mediator effect

\section{Introduction}

Multiple changes in the structure of families and the composition of the workforce, such as increasing numbers of dual-earner couples and new expectations of men as parents, have led many North American employees to experience difficulties reconciling the conflicting demands of their roles as workers and parents (Butts, Casper, \& Yang, 2013; Janzen, Muhajarine, \& Kelly, 2007). In addition, data from recent studies indicate that reconciling work and family is a major concern for working parents (Breaugh \& Frye, 2008; St-Amour, Laverdure, Devault, \& Manseau, 2005), particularly for managers and professionals, who are among the workers most at risk of experiencing high levels of interrole conflict (Duxbury \& Higgins, 2003).

Although the negative impacts of interrole conflicts on health, particularly psychological distress, have been widely demonstrated, some authors have looked beyond the direct consequences of these conflicts to focus on individual characteristics that may mediate this relationship (Allen, Herst, Bruck, \& Sutton, 2000; McMillan \& Morris, 2012). Social problem solving (SPS) is one of the characteristics identified as a mediator between day-to-day problems and psychological distress (Bell \& D'Zurilla, 2009; Kant, D'Zurilla, \& Maydeu-Olivares, 1997). The SPS concept is described as an individual process that leads to identifying or discovering effective ways of adjusting to difficult situations (D’Zurilla \& Nezu, 1982).

Considering the increase in interrole conflicts experienced by managers and professionals as well as the health consequences of these conflicts, the main objective of this study is to determine whether SPS is a mediator between interrole conflicts and psychological distress. From the management and human resources development perspective, identifying such a mediator effect is crucial, because it may help identify specific organizational interventions that could be implemented to improve the individual capacity of managers to adjust to such conflicts.

\section{Literature Review}

\subsection{Interrole Conflict}

The view of interrole conflict that traditionally dominates the literature (Parasuraman \& Greenhaus 2002) explains that the demands arising from undertaking multiple roles place the individual in a situation in which they have insufficient personal resources. The problem lies in an individual's ability to use their energies and talents in an optimal way in order to reduce the overall pressure to an acceptable level (Goode, 1960; Sieber, 
1974). When the pressure exerted by one role limits an individual's ability to respond to the requirements of other life roles, the individual is confronted with an interrole conflict (Greenhaus \& Beutell, 1985).

Earlier research seems to have considered this relationship from a unidirectional point of view in which work interferes with family (WIF). It has been subsequently shown that this relationship is bidirectional, as family may also interfere with work (FIW). However, these two forms of conflict remain linked without being highly correlated (Carlson \& Frone, 2003). Although these forms of interrole conflict are largely independent as regards their antecedents and consequences (Byron, 2005; Frone, Russell, \& Cooper, 1992), it has been established that WIF tends to occur more often than FIW (Frone, 2003; Frone \& Russell, 1992). In their meta-analysis, Allen et al. (2000) also report the predominance of WIF and conclude that one of the most consistent findings in the literature they consulted was the significant relationship between WIF and various stress-related consequences, the most worrisome being depression.

\subsection{Psychological Distress}

The conflict between their roles as workers and parents can affect many aspects of people's lives, be it at work, at home, their marriage or their physical and psychological health (Eby, Casper, Lockwood, Bordeaux \& Brinley, 2005). On the psychological level, some authors have considered the link between work-family conflict and life satisfaction, as well as job satisfaction and family life (Ford, Heinen, \& Langkamer, 2007). However, others have addressed the consequences of these conflicts for psychological health in terms of distress (Rantanen, Pulkkinen, \& Kinnunen, 2005). Distress is defined resulting from a state of tension and stress, and is characterized by anxiety, depression, irritability, lowered self-esteem and social withdrawal (Morin \& Gagné, 2009).

\subsection{Problem Solving}

Social problem solving is defined as the cognitive and behavioral self-directed process by which an individual attempts to find effective solutions to the problems encountered in their normal surroundings (D'Zurilla \& Nezu, 1982). The SPS process is not limited to any particular type of problem, but to everyday situations that can affect a person's functioning. These situations can originate externally (e.g., requests to perform tasks), from within the individual (e.g., personal goal, need or commitment) or from the individual's relationships with others (e.g., professional, marital or parental conflict) (D'Zurilla, Nezu, \& Maydeu-Olivares, 2004). They may be linked to major negative life events (e.g., loss of a loved one or one's job), to recurring or occasional everyday events (e.g., missing the bus, repeated demands from a superior) or a combination of these two types of events, as they may influence each other (Nezu \& Ronan, 1985). These problematic situations can have both a direct (Nezu, 2004) and an indirect effect on an individual's level of psychological distress, through the problem-solving process the individual uses (Bell \& D’Zurilla, 2009).

The purpose of problem solving is to reduce the distress that is experienced, depending on the circumstances (D'Zurilla, Nezu \& Maydeu-Olivares, 2004). The ability to solve social problems is a multidimensional construct with two cognitive components related to the individual's general problem orientation and three behavioral components representing the individual's problem-solving style. A constructive approach to SPS is characterized by a positive problem orientation, which facilitates rational problem solving and helps achieve the expected results more readily. Positive problem orientation refers to the individual's overall disposition to 1) perceive problems as challenges rather than threats, 2) believe that problems can be solved (optimism), 3) believe in their own abilities to solve problems, and 4) recognize that successful problem solving takes time, effort and perseverance and 5) commit to solving problems rather than avoiding them. Rational problem solving is the methodical and deliberate application of effective problem-solving skills. Faced with a problem, an individual who adopts this problem-solving style will tend to gather the facts, identify obstacles, set realistic goals, generate a sufficient number of potential solutions, evaluate their consequences, compare these solutions and choose the best or most effective one, implement the chosen solution, and then monitor and evaluate the results.

In contrast, a dysfunctional SPS approach is characterized by a negative problem orientation combined with an impulsive-careless or an avoidance problem-solving style. Such an approach to problems leads to hasty, partial or delayed attempts at a solution, making it difficult to achieve the desired objectives. Negative problem orientation implies the individual's general tendency to: 1) see problems as threats to their well-being, 2) doubt their own ability to solve problems effectively and 3) become frustrated when faced with problems. An impulsive-careless style is characterized by use of disorganized problem-solving strategies, which result in attempts that are generally limited, impulsive, careless, hasty and incomplete. Solutions are identified hurriedly, regardless of their consequences, and are then implemented without adequately monitoring or evaluating them. Avoidance is an evasive style characterized by procrastination, passivity or inaction. It denotes a marked 
avoidance of problems in the hope that they will resolve themselves or that a third party will take responsibility for them.

According to this model, problem solving is a process of adjustment which, when effective, prevents the adverse effects of the problems of day-to-day life from affecting an individual's physical and psychological health (Nezu, Wilkins, \& Nezu, 2004). Conversely, ineffective problem solving can be associated with various negative consequences such as psychological distress. Several studies have confirmed this relationship by demonstrating that low levels SPS skills are linked to a set of internalizing disorders including depression and anxiety, but also certain externalizing disorders such as substance abuse and aggression (Chang, D'Zurilla, \& Sanna, 2004). Some studies have focused specifically on the mediator effect of SPS in the relationship between day-to-day problems and their negative health effects. Identifying variables involved in mediating the relationship between two variables is the focus of increasing interest (Rascle \& Irachabal, 2001) because it can clarify the often obscure nature of the relationship, in this case, between certain psychological factors and an individual's health. Moreover, for researchers with a practical interest in professional and personal development programs, examining the mediator effect is of great importance in identifying the critical elements of these programs (MacKinnon \& Luecken, 2008).

A study by Bell and D'Zurilla (2009) examined the mediator role of problem solving in the relationship between day-to-day problems and their impact on health. The study considered both internalizing (psychological distress, somatic complaints) and externalizing (aggressive, rule-breaking and intrusive behaviors) symptoms. The results showed that among women, dysfunctional components in SPS mediates the relationship between problems and both internalizing and externalizing symptoms. Among men, only negative problem orientation appears to act as a mediator, and then only for internalizing symptoms. This result is consistent with a number of studies that highlight the important role of negative problem orientation in the adjustment process of individuals (Gosselin, Dugas, \& Ladouceur, 2002; Londahl, Tverskoy, \& D'Zurilla, 2005; McMurran \& Christopher, 2009), particularly its role as a mediator in the relationship between day-to-day problems and psychological distress (Kant et al., 1997).

\subsection{Objectives and Research Hypotheses}

Studies have not addressed the relationship between problem solving and interrole conflict while taking into account the direction of the interference between work and family. However, examining this issue could help characterize the effect of these conflicts on various populations, particularly considering the distinctive natures of WIF and FIW. Moreover, although it has been shown that interrole conflicts are experienced by both sexes, research on the psychological distress that results from these conflicts is almost entirely limited to examining the effects on women. However, in the early 1990s, Barnett, Marshall and Pleck (1992) raised the importance of moving from a monolithic perception - that of men as workers - to a pluralistic view of men's multiple roles. From this point of view, the quality of experiences in other areas of their lives, including in the family sphere, could also be linked to men's health. Therefore, this study seeks to examine the mediator role of SPS on the relationship between certain problem situations arising in day-to-day life (i.e., bidirectional conflict between work and family) and psychological distress in men.

Accordingly, the following research hypotheses were formulated: H1) there is a positive correlation between the two forms of interrole conflict (i.e., between WIF and FIW); H2) there is a positive correlation between interrole conflict and psychological distress; and H3) social problem solving ability acts as a mediator in the relationship between interrole conflict (i.e., WIF or FIW) and psychological distress.

\section{Method}

\subsection{Procedure and Participants}

A non-probability sampling method was used and the sample was composed of volunteers. Participants were drawn from public business directories across the province of Quebec, Canada, and contacted mainly by email. Data was collected using an online questionnaire. Although age and marital status were immaterial, participants in the study had to be male, work as a manager or professional, live in a spousal relationship, and have at least one dependent child living with them either full- or part-time. The final sample had a total of 291 participants.

The vast majority of the participants were managers $(86 \%)$. Nearly three-quarters $(72 \%)$ worked in the private sector and over two-thirds (68\%) were employees. Just over half (52\%) worked for an organization with 50 employees or less. They all worked full-time and an average of 46.53 hours (SD $=9.09$ hours) per week, including overtime. They had an average of 2.24 children $(\mathrm{SD}=1.04)$ and full-time parental responsibility in most cases $(80 \%)$. The vast majority of participants (79\%) were less than 49 years old. The highest academic 
degree obtained by most participants $(86 \%)$ was university level. Finally, most of the participants' spouses had paid employment (87\%) and more than three-quarters (79\%) worked full-time. The gross family income was greater than or equal to $110,000 \mathrm{CAD}$ for $64 \%$ of the couples.

\subsection{Instruments}

Interrole conflicts. a French-language scale for interrole conflict derived from the work of Burley (1989), consists of two subscales of four items each to assess the interference of work with family life (WIF) and family life with work (FIW). Participants indicate their level of agreement on a Likert scale (' 1 = Strongly disagree' to ' 6 = Strongly agree') for each of the eight statements. Factor analysis carried out by the authors of the scale showed a two-factor structure explaining $67.8 \%$ of the total variance, with alpha coefficients of .88 (WIF) and .79 (FIW). In the current study, these coefficients were respectively .84 and .71 .

Psychological distress. Based on the Psychiatric Symptom Index (Ilfeld, 1976), the French abridged version of the Psychological Distress Index from the Quebec Health Survey (PDIQHS) was used to measure various symptoms associated with the concept of psychological distress (Préville, Boyer, Potvin, Perrault, \& Légaré, 1992). The research instrument uses a Likert-type scale (' $1=$ Never' to ' $4=$ Very often') to assess the frequency of symptoms of distress over the last seven days. This 14-item index has good psychometric qualities and an alpha coefficient of .89 for all the items was found in the original study. In the context of the current study, the alpha coefficient was 91 .

Problem solving. The French adaptation (Gosselin et al., 2002) of the Social Problem-Solving Inventory Revised (SPSI-R) by Maydeu-Olivares and D'Zurilla (1996) consists of 52 items assessing how individuals think, feel or behave when faced with day-to-day problems. Participants indicate how representative of themselves each statement is on a Likert-type scale (' $1=$ Not at all true of me' to ' $5=$ Very true of me'). The inventory contains five subscales: 1) positive problem orientation (PPO: 5 items); 2) negative problem orientation (NPO: 10 items); 3) rational problem solving (RPS: 20 items); 4) impulsive-careless style (ICS: 10 items); 5) avoidance style (AS: 7 items). The factor structure of the original English version was demonstrated using confirmatory analysis and the alpha coefficients for the five subscales ranged from .76 to .95 (D'Zurilla, Nezu, \& Maydeu-Olivares, 2002). The French adaptation by Gosselin et al. (2002) has similar psychometric properties to the original. The alpha coefficients for this study were .68 (PPO), .88 (NPO), .92 (RPS), . 79 (ICS) and .81 (AS).

\section{Results}

A correlation matrix was produced (Table 1) prior to testing the mediator role of SPS in the relationship between each form of interrole conflict (WIF or FIW) and psychological distress (as measured by the PDIHQS). Although some correlations are significant, the coefficient values are not large enough to indicate a collinearity problem. Table 1 shows a significant relationship between WIF and FIW $(r=.50, p<.001)$ and between both types of interrole conflicts and psychological distress ( $r=.33, p<.001$ for WIF, $r=.35, p<.001$ for FIW). In addition, as expected, there is a significant relationship between the two components of constructive problem solving, namely PPO and RPS $(r=.57, p<.001)$, and between the components of dysfunctional problem solving, namely NPO and ICS $(r=.47 p<.001)$, NPO and AS $(r=.65, p<.001)$, and ICS and AS $(r=.53, p<.001)$. In addition, the components of dysfunctional problem solving show a significant relationship $(r>.30)$ with distress and interrole conflicts (WIF, FIW); in particular, NPO exhibits a strong correlation with psychological distress $(r$ $=.58, p<.001)$. 
Table 1. Intercorrelations, means and standard deviations of study variables $(\mathrm{N}=291)$

\begin{tabular}{lcccccccr} 
Variable & 1 & 2 & 3 & 4 & 5 & 6 & 7 & 8 \\
\hline 1. WIF & 1 & & & & & & & \\
2. FIW & $0.50^{* * *}$ & 1 & & & & & & \\
3. PPO & -0.08 & $-0.15^{* *}$ & 1 & & & & & \\
4. NPO & $0.22^{* * *}$ & $0.35^{* * *}$ & $-0.46^{* * *}$ & 1 & & & & \\
5. RPS & $-0.11^{*}$ & $-0.10^{*}$ & $0.57^{* * *}$ & $-0.22^{* * *}$ & 1 & & & \\
6. ICS & $0.14^{* *}$ & $0.22^{* * *}$ & $-0.16^{* *}$ & $0.47^{* * *}$ & $-0.40^{* * *}$ & 1 & & \\
7. AS & $0.16^{* *}$ & $0.36^{* * *}$ & $-0.36^{* * *}$ & $0.65^{* * *}$ & $-0.24^{* * *}$ & $0.53^{* * *}$ & 1 & \\
8. PDIQHS & $0.33^{* * *}$ & $0.35^{* * *}$ & $-0.17^{* *}$ & $0.58^{* * *}$ & -0.08 & $0.35^{* * *}$ & $0.37^{* * *}$ & 1 \\
\hline Mean & 3.33 & 2.39 & 13.15 & 7.00 & 46.62 & 7.67 & 3.89 & 23.07 \\
SD & 1.22 & 1.00 & 3.34 & 5.93 & 12.77 & 5.20 & 4.05 & 15.05 \\
\hline
\end{tabular}

Note: WIF $=$ Work interference with family; FIW $=$ Family interference with work, $P P O=$ Positive problem orientation, NPO $=$ Negative problem orientation, RPS $=$ Rational problem solving, ICS = Impulsive-careless style, AS = Avoidance style, $\mathrm{PDIQHS}=$ Psychological Distress Index from the Quebec Health Survey.

${ }^{*} p<0.05 .{ }^{* *} p<0.01$. ${ }^{* *} p<00.001$

The mediator effect of SPS was tested using the method proposed by Baron and Kenny (1986). For an effect to qualify as a mediator, three conditions must be met. First, the independent variable (i.e., interrole conflicts) must be associated with the mediating variable (i.e., components of problem-solving ability). Secondly, the mediating variable must be associated with the dependent variable (i.e., psychological distress). Thirdly, the independent variable must be correlated with the dependent variable. A mediator effect is observed when the relationship between the independent variable and the dependent variable is significantly reduced when the mediating variable is taken into account. If the relationship is no longer significant when the mediating factor is included, mediation is said to be complete; otherwise, mediation is described as partial. Several tests can be used to determine whether the observed mediator effect is significant, with Sobel's test (1982) being the most common (MacKinnon, Fairchild, \& Fritz, 2007). However, application of Sobel's test is based on the assumption of normal distribution (MacKinnon \& Fairchild, 2009). Since it is difficult to assume normal distribution when identifying mediator effects, the asymmetric confidence intervals were calculated to increase the statistical power of the analyses (MacKinnon, Lockwood, Hoffman, West, \& Sheets, 2002). The PRODCLIN program (Version 2; MacKinnon, Fritz, Williams, \& Lockwood, 2007) enables calculation of upper and lower confidence interval limits. If zero does not fall between these limits, the mediator effect is considered significant.

Based on the SPS process (see Figure 1), path analysis was carried out to verify the mediation conditions described above. As path analysis uses multiple regression, some checks were made. First, the sample size needed to detect the mediator effect was calculated using the guidelines proposed by Fritz and MacKinnon (2007). This revealed that the sample size required to obtain a power of .80 for the Sobel test and the asymmetric confidence interval test was smaller than the overall sample size used in this study. Therefore, the analysis had the power necessary to identify any mediator effects. Multivariate analyses was then carried out (i.e., calculation of the Mahalanobis distance, the Cook distance and the leverage), showing that there were no extreme value that might compromise the results of the analysis. Finally, compliance with normality, homoscedasticity and linearity assumptions was verified by examining the residual scatterplots produced by the regression equations; no pattern of relationships was apparent and the points seemed to be distributed randomly. These checks thus support the robustness of the analysis conducted. 


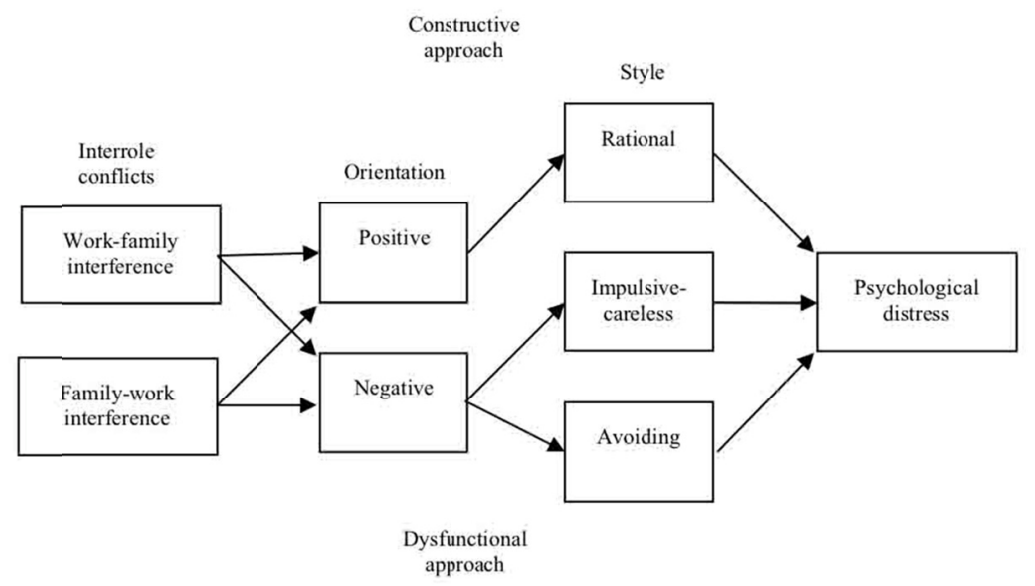

Figure 1. Process of resolving interrole conflicts in relation to psychological distress, based on the five-component model for social problem solving developed by D'Zurilla and colleagues (2002)

For the path analysis, multiple regression was performed on each of the model's endogenous variables (i.e., psychological distress and components of problem solving ability) as a function of each of the variables above, for a total of six multiple regressions. The results indicated that only two problem-solving components - NPO and ICS-satisfy Baron and Kenny's conditions (1986) and could explain the relationship between FIW and psychological distress. However, the unique contribution (squared semi-partial correlation) of ICS to the explained variance of psychological distress was negligible $\left(\mathrm{Sr}^{2}=.009\right)$ in the model. Consequently, only NPO, with a proportion of explained variance for psychological distress of $13.4 \%\left(S r^{2}=.134\right)$ was identified as a mediating variable for the subsequent analyses.

As the relationship between FIW and psychological distress became non-significant when NPO was statistically controlled, the observed mediator effect is considered complete. This effect was significant on the Sobel test $(Z=$ $4.56, p<.001$ ) and the asymmetric confidence interval analysis confirmed the result (see Table 2 ). The variance of psychological distress explained by this mediator model was .38 (adjusted $R^{2}, p<.001$ ).

Table 2. Standardized regression coefficients for family interference with work before and after statistical control of negative problem orientation (NPO) in predicting psychological distress $(\mathrm{N}=291)$

\begin{tabular}{cccccc}
\hline $\begin{array}{c}\text { NPO } \\
\text { Before control }\end{array}$ & $\begin{array}{c}\text { NPO } \\
\text { After control }\end{array}$ & Sobel's test & \multicolumn{2}{c}{$\begin{array}{c}\text { Asymmetric confidence } \\
\text { interval }^{\mathrm{a}}(p<0.05)\end{array}$} \\
\cline { 2 - 5 } & $\beta$ & $\beta$ & $\mathrm{Z}$ & Lower limit Upper limit \\
\hline $0.25^{* * *}$ & 0.08 & $4.56 * * *$ & 1.49 & 3.65 \\
\hline
\end{tabular}

${ }^{a}$ When the confidence interval does not contain the value 0 , the mediator effect is significant. ${ }^{*} p<0.05$. ${ }^{* *} p<0.001 .{ }^{* * *} p<0.001$.

In summary, in confirmation of our hypotheses, the analyses revealed a significant positive relationship between FIW and WIF (H1) and a significant positive relationship between interrole conflicts and psychological distress (H2). The results also demonstrated a mediator role for negative problem orientation in the relationship between family interference with work and psychological distress (H3).

\section{Discussion}

The main aim of this study was to test the mediator effect of SPS in the relationship between interrole conflicts and psychological distress. The results show a moderate relationship exists between WIF and FIW. Insofar as these two forms of interference between family and work may influence each other, a link between these them is generally expected, although the two concepts are considered to be distinct (Mesmer-Magnus \& Viswesvaran, 2004). Our results also show that both types of interrole conflicts are moderately related to psychological distress. Thus, the larger the number of interrole conflicts, the higher the level of psychological distress, regardless of the source of interference. This result shows that the psychological distress reported by the participants is not only dependent on the pressures and demands of their professional life, but also on those arising in the domestic 
sphere. It is thus possible to argue that the quality of their experiences in their various life roles, including those at work and within the family, may affect men's psychological health (Barnett et al., 1992).

Our results also show that psychological distress is mainly associated with components of dysfunctional problem-solving, particularly negative problem orientation, which shows a strong correlation with distress. This result is consistent with earlier findings (D'Zurilla et al., 2002; Nezu et al., 2004). However, the relationship between two variables may be overestimated when they are evaluated using the same method. Thus, self-reporting tools measuring negative dimensions (NPO and distress) may have produced higher correlation coefficients due to factors related to personality such as negative affect or acquiescence (Spector, 2006).

In addition to the direct effects identified, the results of this study support the third research hypothesis concerning the role of social problem solving ability, specifically NPO, as a mediator between FIW and psychological distress. The mediator effect of NPO is consistent with the results of Bell and D'Zurilla (2009) as well as those of Kant and colleagues (1997) regarding depression and anxiety in men. The mediator effect identified in this study appears to be complete, suggesting that overall psychological distress predicted by FIW can be explained entirely by the men's negative problem orientation with regard to interrole conflicts.

Thus, in the specific context of the relationship between FIW and psychological distress among managers and professionals, the mediator effect of problem solving does not seem to involve both cognitive and behavioral processes; rather it is essentially of a cognitive nature. The effect stems from the tendency of some men to adopt a negative problem orientation, that is to say, to consider family interference with work as a threat to their well-being, to doubt their own abilities to resolve such conflicts, and to become frustrated when they do occur. As the organizational environment is generally less responsive than the family sphere and as this situation does not seem to be improving (Conseil consultatif du travail et de la main-d'oeuvre, 2001; Najem \& Tremblay, 2010), it is possible that managers and professionals immediately perceive family interference with work as a difficult issue to deal with, one which is thus ipso facto associated with psychological distress through the mediating effect of NPO. This societal reality could also explain the absence of a mediator effect for NPO in the relationship between WIF and psychological distress. To the extent that families are usually more flexible than the workplace, interference from work may be viewed as less problematic for men, as they can rely on the adaptability of the family environment.

The relationship between WIF and men's psychological distress may thus be mediated by factors other than negative problem orientation. This explanation would be consistent with the findings of the study by Pearlin and Schooler (1978) on the psychological resources mobilized and the coping strategies used in response to problems in various life roles (i.e., spouse, parent, work and household economy), and their relationship with decreasing psychological distress. Their results indicated that psychological characteristics (e.g., self-esteem, locus of control) prove more useful in managing problems that are the most difficult for the individual to control, such as work and the family economy, whereas coping strategies (e.g., those designed to change a situation or to limit its consequences or effects) are more effective in areas where concrete efforts can make a difference, such as in the roles of parent and spouse. Further research is needed to investigate the influence that the degree of control individuals have in various spheres of life-including the flexibility or inflexibility of the organizational environment-may have on the relationship between interrole conflicts and psychological distress.

It might also be appropriate to focus on how the effective resolution of interrole conflicts has positive effects on psychological health. To this end, we propose extending the model to examine the specific contribution of the constructive problem-solving process and its components, particularly positive problem orientation. This would provide a more complete picture of the role of social problem solving in the complex relationship between involvement in multiple life roles - at work and in the family - and impacts on men's health, especially their psychological well-being.

\section{Conclusion}

The purpose of this study was to gain a better understanding of the sources of psychological distress in men - a population often overlooked - by examining interrole conflicts and their impact on psychological health. It makes an original contribution by examining the role of social problem solving in mediating the relationship between interrole conflicts and psychological distress in a population particularly at risk of experiencing such conflicts, namely managers and professionals.

The main limitations of this study are methodological. First, it uses a cross-sectional design that provides only a snapshot of the measured variables. As MacKinnon and Fairchild (2009) assert, the existence of a mediator effect over time can only be demonstrated by a longitudinal study. In addition, the sample is composed of male managers and professionals living almost exclusively in two-income families, limiting the extent to which 
generalizations can be made based on our results. Furthermore, it is possible that the voluntary participation of the fathers in this study was motivated by their increased interest in family-related matters, which raises questions about how representative they are of men in general. Finally, measurements of interrole conflict, problem solving and psychological distress were all self-reported, which can introduce a mono-method bias and artificially amplify the observed relationships (Spector, 2006).

One of the most important contributions of this study concerns the role of negative problem orientation, identified as a mediator of the relationship between family interference with work and psychological distress. From a human resources viewpoint, this result raises questions about developing intervention programs designed to improve managers' problem-solving skills in the context of interrole conflicts or situations that are not under their control. It could be particularly relevant to examine the use of intervention techniques focused solely on competencies - rational problem solving, for example - without addressing attitude or orientation to problems. It would also be desirable, as suggested by D'Zurilla, Chang and Sanna (2004), to conduct further research on how we assess the effectiveness of programs targeting the development of problem-solving skills for managers and professionals. If such programs were shown to be effective in benefiting the health of individuals, they would be equally beneficial for organizations, workers and their families.

\section{References}

Allen, T. D., Herst, D. E. L., Bruck, C. S., \& Sutton, M. (2000). Consequences associated with work-to-family conflict: A review and agenda for future research. Journal of Occupational Health Psychology, 5(2), 278-308. http://dx.doi.org/10.1037/1076-8998.5.2.278

Barnett, R. C., Marshall, N. L., \& Pleck, J. H. (1992). Men's multiple roles and their relationship to men's psychological distress. Journal of Marriage and Family, 54(2), 358-367. http://dx.doi.org/10.2307/353067

Baron, R. M., \& Kenny, D. A. (1986). The moderator-mediator variable distinction in social psychological research: Conceptual, strategic, and statistical considerations. Journal of Personality and Social Psychology, 51(6), 1173-1182. http://dx.doi.org/10.1037/0022-3514.51.6.1173

Bell, A. C., \& D'Zurilla, T. J. (2009). The influence of social problem-solving ability on the relationship between daily stress and adjustment. Cognitive Therapy and Research, 33(5), 439-448. http://dx.doi.org/10.1007/s10608-009-9256-8

Breaugh, J. A., \& Frye, N. K. (2008). Work-family conflict: The importance of family-friendly employment practices and family-supportive supervisors. Journal of Business and Psychology, 22(4), 345-353. http://dx.doi.org/10.1007/s10869-008-9081-1

Burley, K. A. (1989). Work-family conflict and marital adjustment in dual career couples: A comparison of three time models. Claremont Graduate University.

Butts, M. M., Casper, W. J., \& Yang, T. S. (2013). How important are work-family support policies? A meta-analytic investigation of their effects on employee outcomes. Journal of Applied Psychology, 98(1), 1-25. http://dx.doi.org/10.1037/a0030389

Byron, K. (2005). A meta-analytic review of work-family conflict and its antecedents. Journal of Vocational Behavior, 67(2), 169-198. http://dx.doi.org/10.1016/j.jvb.2004.08.009

Carlson, D. S., \& Frone, M. R. (2003). Relation of behavioral and psychological involvement to a new four-factor conceptualization of work-family interference. Journal of Business and Psychology, 17(4), 515-535. http://dx.doi.org/10.1023/A:1023404302295

Chang, E. C., D’Zurilla, T. J., \& Sanna, L. J. (2004). Social problem solving: Theory, research, and training. Washington, DC: American Psychological Association. http://dx.doi.org/10.1037/10805-000

Conseil consultatif du travail et de la main-d'oeuvre (Advisory Council on Workplace and Labour Affairs). (2001). Concilier travail et famille : un défi pour les milieux de travail. Un plan d'action [Reconciling work and family: A challenge for the workplace. An action plan]. Quebec: Government of Quebec.

Duxbury, L. E., \& Higgins, C. A. (2003). Work-Life Conflict in Canada in the New Millennium: A Status Report. Ottawa: Department of Community Health, Health Canada.

D’Zurilla, T. J., \& Nezu, A. M. (1982). Social problem-solving in adults. In P. Kendal (Éd.), Advances in cognitive-behavioral research and therapy (Vol. 4, pp. 201-274). New York: Academic Press.

D'Zurilla, T. J., Chang, E. C., \& Sanna, L. J. (2004). Social problem solving: Current status and future directions. In E. C. Chang, T. J. D’Zurilla \& L. J. Sanna (Eds.), Social Problem Solving: Theory, Research, and Training 
(pp. 241-253). Washington, DC: American Psychological Association. http://dx.doi.org/10.1037/10805-014

D'Zurilla, T. J., Nezu, A. M., \& Maydeu-Olivares, A. (2002). Social problem-solving inventory-revised (SPSI-R): Technical manual. North Tonawanda: Multi-Health Systems.

D'Zurilla, T. J., Nezu, A. M., \& Maydeu-Olivares, A. (2004). Social Problem Solving: Theory and Assessment. In E. C. Chang \& T. J. D’Zurilla (Eds.), Social Problem Solving: Theory, Research, and Training (pp. 11-27). Washington, DC: American Psychological Association. http://dx.doi.org/10.1037/10805-001

Eby, L. T., Casper, W. J., Lockwood, A., Bordeaux, C. \& Brinley, A. (2005). Work and family research in IO/OB: Content analysis and review of the literature (1980-2002). Journal of Vocational Behavior, 66(1), 124-197. http://dx.doi.org/10.1016/j.jvb.2003.11.003

Fairchild, A. J., \& MacKinnon, D. P. (2009). A general model for testing mediation and moderation effects. Prevention Science, 10(2), 87-99. http://dx.doi.org/10.1007/s11121-008-0109-6

Ford, M. T., Heinen, B. A., \& Langkamer, K. L. (2007). Work and family satisfaction and conflict: A meta-analysis of cross-domain relations. Journal of Applied Psychology, 92(1), 57-80. http://dx.doi.org/10.1037/0021-9010.92.1.57

Fritz, M. S., \& MacKinnon, D. P. (2007). Required sample size to detect the mediated effect. Psychological Science, 18(3), 233-239. http://dx.doi.org/10.1111/j.1467-9280.2007.01882.x

Frone, M. R. (2003). Work-family balance. In J. C. Quick \& L. E. Tetrick (Eds.), Handbook of Occupational Health Psychology (pp. 143-162). Washington, DC, US: American Psychological Association. http://dx.doi.org/10.1037/10474-007

Frone, M. R., \& Russell, M. (1992). Prevalence of work-family conflict: Are work and family boundaries asymmetrically permeable? Journal of Organizational Behavior, 13(7), 723-729. http://dx.doi.org/10.1002/job.4030130708

Frone, M. R., Russell, M., \& Cooper, M. (1992). Antecedents and outcomes of work-family conflict: Testing a model of the work-family interface. Journal of Applied Psychology, 77(1), 65-78. http://dx.doi.org/10.1037/0021-9010.77.1.65

Goode, W. J. (1960). A theory of role strain. American Sociological Review, 25(4), 483-496. http://dx.doi.org/10.2307/2092933

Gosselin, P., Dugas, M. J., \& Ladouceur, R. (2002). Inquiétude et résolution de problèmes sociaux: Le rôle de l'attitude négative face au problème [Worry and problem solving: The role of negative problem orientation]. Journal de Thérapie Comportementale et Cognitive, 12(2), 49-58.

Greenhaus, J. H., \& Beutell, N. J. (1985). Sources and conflict between work and family roles. Academy of Management Review, 10(1), 76-88. http://dx.doi.org/10.2307/258214

Ilfeld, F. W. (1976). Further validation of a psychiatric symptom index in a normal population. Psychological Reports, 39(3, Pt 2), 1215-1228. http://dx.doi.org/10.2466/pr0.1976.39.3f.1215

Janzen, B. L., Muhajarine, N., \& Kelly, I. W. (2007). Work-family conflict, and psychological distress in men and women among Canadian police officers. Psychological Reports, 100(2), 556-562. http://dx.doi.org/10.2466/PR0.100.2.556-562

Kant, G. L., D’Zurilla, T. J., \& Maydeu-Olivares, A. (1997). Social problem solving as a mediator of stress-related depression and anxiety in middle-aged and elderly community residents. Cognitive Therapy and Research, 21(1), 73-96. http://dx.doi.org/10.1023/A:1021820326754

Londahl, E. A., Tverskoy, A., \& D'Zurilla, T. J. (2005). The relations of internalizing symptoms to conflict and interpersonal problem solving in close relationships. Cognitive Therapy and Research, 29(4), 445-462. http://dx.doi.org/10.1007/s10608-005-4442-9

MacKinnon, D. P., \& Fairchild, A. J. (2009). Current directions in mediation analysis. Current Directions in Psychological Science, 18(1), 16-20. http://dx.doi.org/10.1111/j.1467-8721.2009.01598.x

MacKinnon, D. P., \& Luecken, L. J. (2008). How and for whom? Mediation and moderation in health psychology. Health Psychology, 27(2, Suppl), S99-S100. http://dx.doi.org/10.1037/0278-6133.27.2

MacKinnon, D. P., Fairchild, A. J., \& Fritz, M. S. (2007). Mediation analysis. Annual Review of Psychology, 58, 593-614. http://dx.doi.org/10.1146/annurev.psych.58.110405.085542

MacKinnon, D. P., Fritz, M. S., Williams, J., \& Lockwood, C. M. (2007). Distribution of the product confidence 
limits for the indirect effect: Program PRODCLIN. Behavior Research Methods, 39(3), 384-389. http://dx.doi.org/10.3758/BF03193007

MacKinnon, D. P., Lockwood, C. M., Hoffman, J. M., West, S. G., \& Sheets, V. (2002). A comparison of methods to test mediation and other intervening variable effects. Psychological Methods, 7(1), 83-104. http://dx.doi.org/10.1037/1082-989x.7.1.83

Maydeu-Olivares, A., \& D'Zurilla, T. J. (1996). A factor-analytic study of the social problem-solving inventory: An integration of theory and data. Cognitive Therapy and Research, 20(2), 115-133. http://dx.doi.org/10.1007/BF02228030

McMillan, H. S., \& Morris, M. L. (2012). Examining the relationship between work/life conflict and life satisfaction in executives: The importance of problem-solving coping interventions and HRD. Advances in Developing Human Resources, 14(4), 640-663. http://dx.doi.org/10.1177/1523422312455626

McMurran, M., \& Christopher, G. (2009). Social problem solving, anxiety, and depression in adult male prisoners. Legal and Criminological Psychology, 14(1), 101-107. http://dx.doi.org/10.1348/135532507X267031

Mesmer-Magnus, J. R., \& Viswesvaran, C. (2004). Convergence between measures of work-to-family and family-to-work conflict: A meta-analytic examination. Journal of Vocational Behavior, 67(2), 215-232. http://dx.doi.org/10.1016/j.jvb.2004.05.004

Morin, E. M., \& Gagné, C. (2009). Donner un sens au travail: Promouvoir le bien-être psychologique [Making work meaningful-Promoting psychological well-being]. Montréal: Institut de recherche Robert-Sauvé en santé et sécurité du travail (Robert-Sauvé Research Institute on Work Health and Safety - IRSST).

Najem, E., \& Tremblay, D. G. (2010). L'incidence des pratiques de conciliation travail-famille dans les milieux de travail canadiens : les milieux syndiqués sont-ils mieux pourvus et la situation s'améliore-t-elle? [The impact of work-family practices in Canadian workplaces: Unionized workplaces are they better equipped and is the situation getting better?] Papers in Political Economy, 41, 1-11.

Nezu, A. M. (2004). Problem solving and behavior therapy revisited. Behavior Therapy, 35(1), 1-33. http://dx.doi.org/10.1016/S0005-7894(04)80002-9

Nezu, A. M., \& Ronan, G. F. (1985). Life stress, current problems, problem solving, and depressive symptoms: An integrative model. Journal of Consulting and Clinical Psychology, 53(5), 693-697. http://dx.doi.org/10.1037/0022-006X.53.5.693

Nezu, A. M., Wilkins, V. M., \& Nezu, C. M. (2004). Social problem solving, stress, and negative affect. In E. C. Chang \& T. J. D'Zurilla (Eds.), Social problem solving: Theory, research, and training (pp. 49-65). Washington, DC: American Psychological Association. http://dx.doi.org/10.1037/10805-003

Parasuraman, S., \& Greenhaus, J. H. (2002). Toward reducing some critical gaps in work-family research. Human Resource Management Review, 12(3), 299-312. http://dx.doi.org/10.1016/S1053-4822(02)00062-1

Pearlin, L. I., \& Schooler, C. (1978). The structure of coping. Journal of Health and Social Behavior, 19(1), 2-21. http://dx.doi.org/10.2307/2136319

Préville, M., Boyer, R., Potvin, L., Perrault, C., \& Légaré, G. (1992). La détresse psychologique : détermination de la fiabilité et de la validité de la mesure utilisée dans l'enquête Santé Québec [Psychological distress: Determining the reliability and validity of the measure used in the Santé Québec Health Survey]. Montréal: Government of Quebec, Ministry of Health and Social Services.

Rantanen, J., Pulkkinen, L., \& Kinnunen, U. (2005). The big five personality dimensions, work-family conflict, and psychological distress: A longitudinal view. Journal of Individual Differences, 26(3), 155-166. http://dx.doi.org/10.1027/1614-0001.26.3.155

Rascle, N., \& Irachabal, S. (2001). Mediators and moderators: Theoretical and methodological implications in stress and health psychology research. Le Travail Humain: A Bilingual and Multi-Disciplinary Journal in Human Factors, 64(2), 97-118. http://dx.doi.org/10.3917/th.642.0097

Sieber, S. D. (1974). Toward a theory of role accumulation. American Sociological Review, 39(4), 567-578. http://dx.doi.org/10.2307/2094422

Sobel, M. E. (1982). Asymptotic confidence intervals for indirect effects in structural equation models. In S. Leinhardt (Éd.), Sociological Methodology (pp. 290-312). Washington, DC: American Sociological Association. 
Spector, P. E. (2006). Method Variance in Organizational Research: Truth or Urban Legend? Organizational Research Methods, 9(2), 221-232. http://dx.doi.org/10.1177/1094428105284955

St-Amour, N., Laverdure, J., Devault, A., \& Manseau, S. (2005). The difficulty of balancing work and family life: Impact on the physical and mental health of Quebec families. Quebec: Institut National de Santé Publique du Québec (Quebec National Public Health Institute).

\section{Copyrights}

Copyright for this article is retained by the author(s), with first publication rights granted to the journal.

This is an open-access article distributed under the terms and conditions of the Creative Commons Attribution license (http://creativecommons.org/licenses/by/3.0/). 